\title{
Planktonic Biodiversity of Bhoj Wetland, Bhopal, India
}

\section{${ }^{1}$ VERMA NEELAM; ${ }^{2}$ BAJPAI AVINASH; ${ }^{3}$ DWIVEDI S.N.}

\author{
${ }^{1}$ Engineering Chemistry Department, VNS Institute of Technology, Bhopal, India, Email: neelamverma.chem@gmail.com \\ ${ }^{2}$ Makhanlal University, Bhopal, India, Email: bajpai.chem@gmail.com \\ ${ }^{3}$ Oriental Research Foundation, Bhopal, India, Email: sndiwedi@gmail.com
}

\begin{abstract}
Biodiversity found on Earth today consists of many millions of distinct biological species, which is the product of nearly 3.5 billion years of evolution. This article deals with planktonic distribution of Bhoj Wetland, Bhopal, India . Bhoj Wetland comprises of two lakes i.e. Upper and Lower lakes of Bhopal. The Upper lake is shallow, highly stratified and oligotrophic lake while Lower lake is eutrophic lake. Samples were collected from Upper lake at two sampling stations and in Lower lakes from three sampling stations with their reference stations. The work was carried out for a period of two year (i.e. 2005-2006) in these contrasting lakes@ JASEM
\end{abstract}

Biological evolution (Darwinian) produced the world in which humankind began; a combination of biological and social evolution produced the world humankind now inhabits; and social evolution will determine whether humankind can live sustainably. It has been commented by Theodosius Dobzhansky that: "Nothing in biology makes sense, except in the light of evolution" (Campbell, N., 1990). Biological diversity or biodiversity is the total variability of all living organism in the ecological complexes (Bajpai, 1994). Biological monitoring of a wetland is an integral part for the management of the total ecological health of the water body and is becoming increasingly important in water quality monitoring and assessment (Bajpai et. al., 2001). Phytoplankton is the base of most lake food webs and fish production is linked to phytoplankton primary production (Ryder et. al., 1974). Phytoplankton assemblages respond rapidly to changes in their environment with concomitant changes in overall abundance, growth rates and species composition, changes in physical and chemical water quality can thus have a rapidly changed species composition (Charles \& Smol, 1994; Dixit et. al., 1992). In most of the lakes Zooplankton are the central trophic link between primary producers and fish. Zooplankton are ubiquitous in all lakes and are quickly and easily sampled in the field (Bajpai et. al., 2001). Many zooplankton species found in north temperate lakes that are cosmopolitan or wide ranging in their distribution (Hutchinson, 1967). Zooplankton species richness in reduced under chemical stresses (Baker \& Christensen, 1991).

Lakes and reservoirs deteriorate through excessive addition of plant nutrients, organic matter and silt, which combines to produce increased algae and rooted plant biomass, reduced water clarity, and usually decreased water volumes (Harper, 1992). Nutrient pollution especially with phosphorus but also with nitrogen coming from urban runoff and sanitary sewer systems can lead to the eutrophication of the receiving water bodies (Stevens, 2003). The most common, obvious and persistent water quality problem is that of the so-called eutrophication (Mason, 1991; Salas \& Martino, 1990). The excessive loading of phosphorus and nitrogen results in high algal biomass, dominance by aquatic bacteria and loss of macrophytes (Jana \& Das, 1995). During the decomposition of water blooms, deoxygenation of waters is observed which can affect the ability of aquatic animals to survive. In this condition water bodies lose much of their attractiveness for recreation, and their usefulness and safety as industrial and domestic water supplies. As a consequence water eutrophication can bring about economic losses in the form of decreased property values, high cost treatments of raw drinking water, illness, depressed recreation industries, expenditures for management and restoration, and ultimately the need to build new reservoirs.

The Bhoj Wetland: Bhoj Wetland, Bhopal comprise of two lakes i.e. Upper and Lower lakes, India. These wetlands are listed amongst the 25 lakes recognized by Ramsar (2007). The twin lakes (i.e. Upper and Lower lakes of Bhopal) have a total water spread area of 32.29 sq. km and catchment area of 370.6 sq. km and both lakes support a rich and diverse range of flora and fauna. The Upper Lake is an elongated water body, constructed by Raja Bhoj in $11^{\text {th }}$ century whereas Lower Lake was constructed by Nawab Chhote Khan in 1794 A.D. It is situated towards the east end of the Upper Lake and is an integral part of the latter. The Lower Lake receives a large amount of raw sewage from it's densely populated habitation.

\section{MATERIAL AND METHODS}

Process of collecting and interpreting representative portions of a resident aquatic community is most important to determine the community structure and 
function. For this, both phytoplankton and zooplankton of wetlands have been taken into consideration. Samples have been collected from the identified stations.

Water samples were filtered through plankton net of different sizes and a total $10 \mathrm{ml}$ was concentrated for every sample. The samples were then preserved by adding lugol's iodine and Formaline solution for zooplankton and phytoplankton respectievely. The standard method i.e. Drop count method for the analysis were followed, as prescribed in APHA (1995).

\section{Study Area}

As the objective of the sampling was to study the distribution of aquatic micro flora and fauna, the samples were chosen to be representative of the entire water quality of the lakes. The present study was conducted in Upper and Lower lakes, Bhopal, India for a period of two years i.e. 2005 \& 2006. For this, five sampling stations were selected along with their reference to compare the status of planktonic species in these lakes. Two stations were in Upper lake and three stations were in Lower lake. The selected stations were Medical college, Khanugaon, Neelam park, Bhoipura and Khatlapura. Reference station was selected at a place, which is away from influence of urban and rural impact of pollution.

Details of sampling stations in Upper lake

(i) Medical College: This station is situated on northeastern part of the lake adjoining medical college. A major inlet joins the lake at this station that brings domestic sewage from the adjoining residential areas (particularly from Shaheed Nagar). This area remained subjected to various developmental activities particularly due to Bhoj Wetland Project.

(ii) Khanugaon: This station is also situated on northern part of the lake and designated as one of the most polluted zones of the lake. This station is also subjected to various anthropogenic activities like bathing, swimming, washing as it is very close to residential area. The station is present in the littoral zone of the lake. Therefore due to availability of light and nutrients many species of macrophytes are flourishing here.

(iii) Reference Station: This station is situated near Takia Island, which is situated in the middle and one of the deepest point of the lake.
Details of sampling sites in Lower lake

(i) Neelam Park: This is one of the most polluted stations of Lower Lake. This station is situated near the densely populated Jehangirabad area and two major sewage inlets join the Lower lake at this station.

(ii) Bhoipura: This sampling station is situated near a densely populated area, named as Bhoipura, where mostly fisherman community lives. Some non-point pollution sources (small drains) join the lake near this site.

(iii) Khatlapura: This sampling station is situated near the Khatlapura temple, which is a major idol immersion site. Apart from this, direct human intervention is also witnessed at this station.

(iv) Reference Station: This sampling station is situated in front of boat club near the island having mazar in the middle of the Lake. As this zone is away from direct human intervention.

\section{RESULTS AND DISCUSSION}

On the basis of finding, distribution of planktons in two lakes at diffrent stations were as follows;

\section{Phytoplankton in Upper lake}

Distribution of phytoplankton species at different sampling stations in Upper lake during the study period is shown in Fig.1.1.

In Medical college (U1) during 2005, total 69 species were recorded in which 31 species (sp) belong to Chlorophyceae, $21 \mathrm{sp}$ belong to Bacillariophyceae, 7 sp Cyanophyceae, 6 sp Euglenophyceae and 4 sp Dinophyceae. In the year 2006, total 76 species were recorded of which 36 sp belong to Chlorophyceae, 21 Bacillariophyceae, 11 Cyanophyceae, 4 Euglenophyceae and 4 Dinophyceae.

In Khanugaon (U2) during 2005, total 61 species were recorded of which $17 \mathrm{sp}$ belong to Chlorophyceae, 28 sp belong to Bacillariophyceae, 7 to Cyanophyceae, 6 to Euglenophyceae and 3 to Dinophyceae whereas in the year 2006, total 79 species were recorded of which $27 \mathrm{sp}$ belong to Chlorophyceae, $38 \mathrm{sp}$ belong to Bacillariophyceae, 7 to Cyanophyceae, 4 to Euglenophyceae and 3 to Dinophyceae.

In Reference station (Ur) during 2005, total 76 species were recorded in which 24 sp Chlorophyceae, 28 sp Bacillariophyceae, 11 sp Cyanophyceae, $7 \mathrm{sp}$ Euglenophyceae and 6 sp Dinophyceae while in the year 2006, total 90 species were recorded of which $24 \mathrm{sp}$ belong to Chlorophyceae, $48 \mathrm{sp}$ Bacillariophyceae, 12 sp Cyanophyceae, $2 \mathrm{sp}$ Euglenophyceae and $4 \mathrm{sp}$ Dinophyceae was found. 
Fig.1.1 Phytoplankton species in different station of Upper lake during year 2005-2006

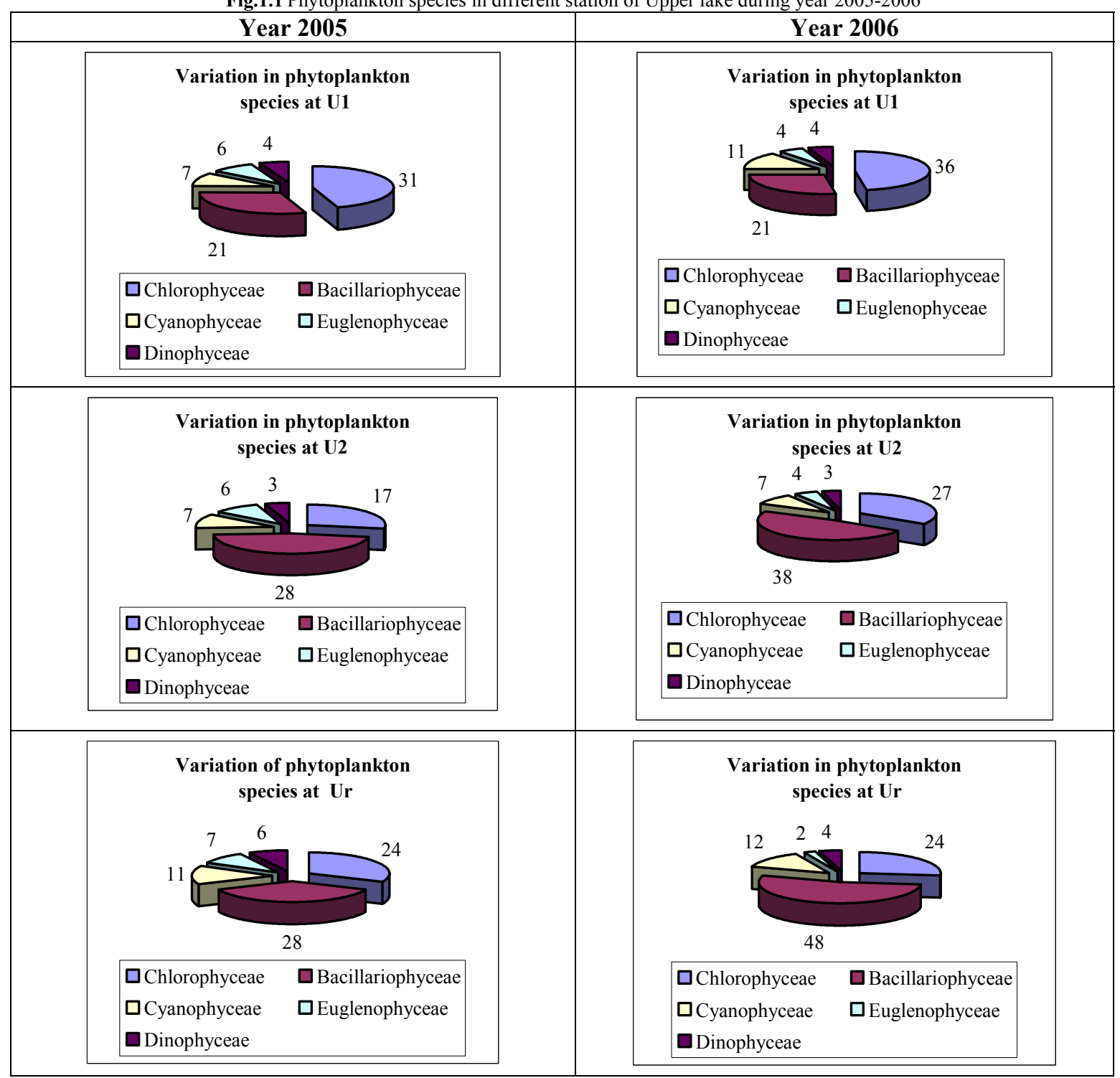

* Corresponding author: Verma Neelam 
Fig.1.2: Phytoplankton species different station of Lower lake during year 2005-2006

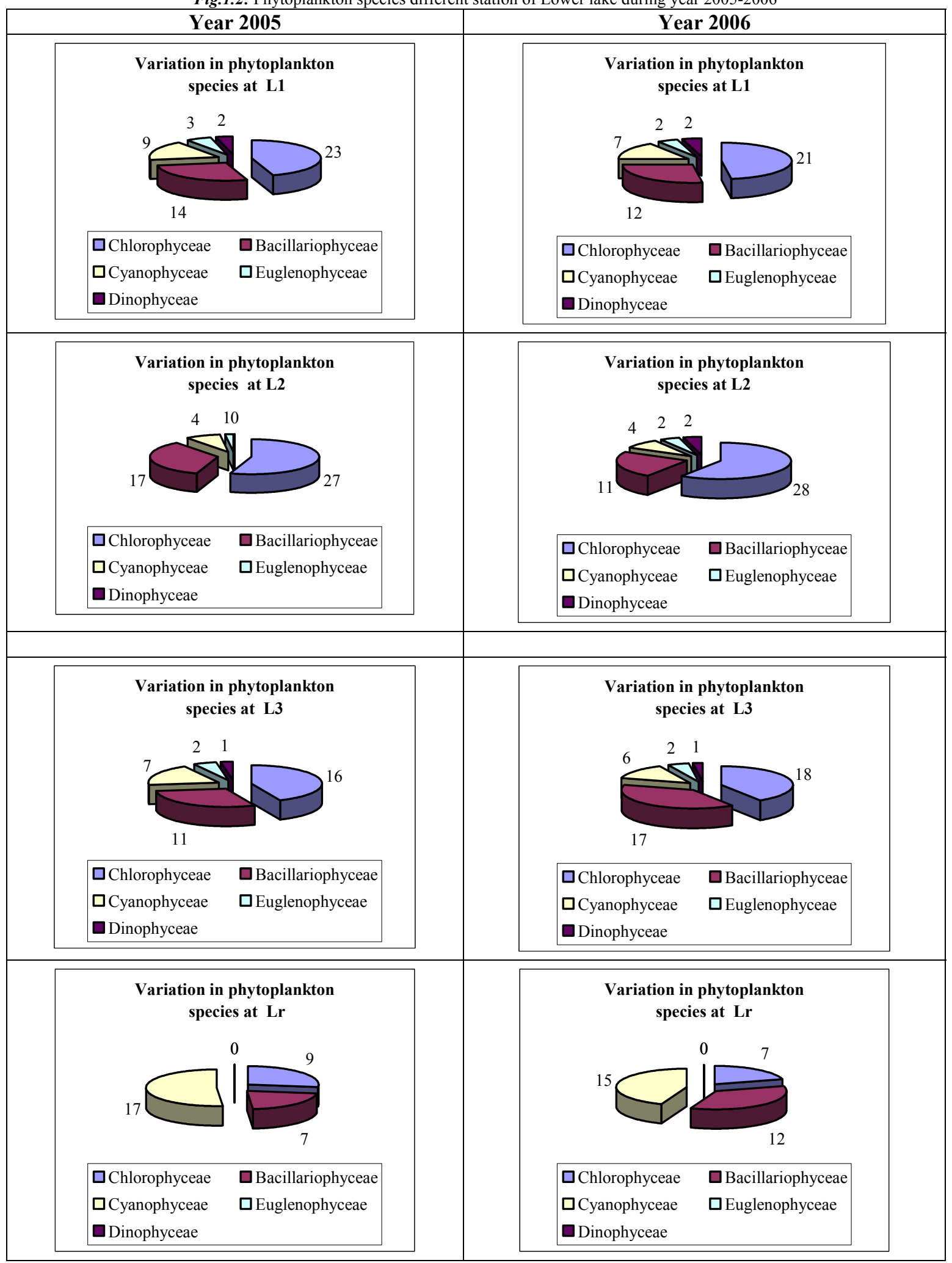

* Corresponding author: Verma Neelam 
Fig.2.1: Zooplankton species in different station of Upper lake during year 2005-2006

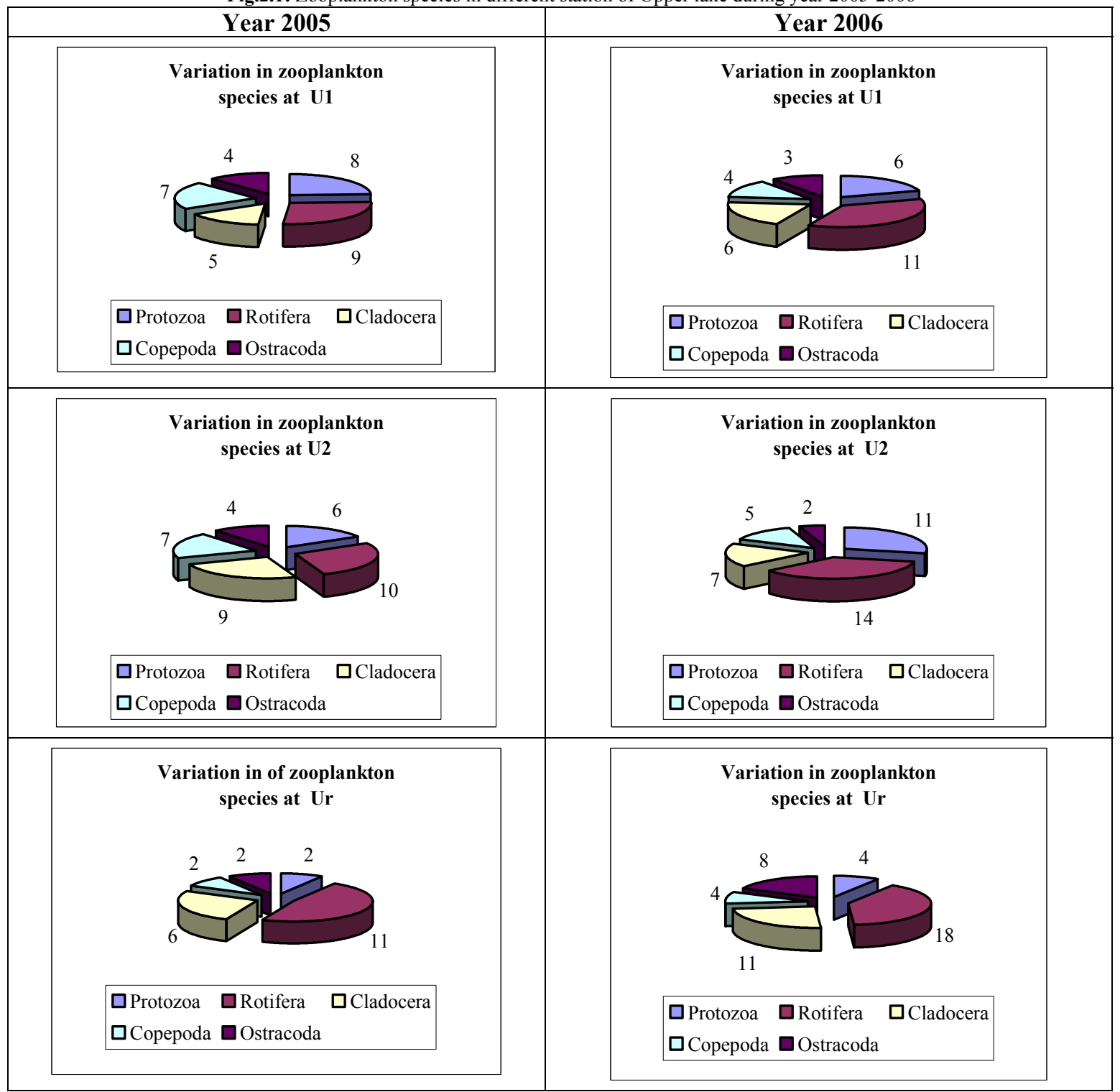

* Corresponding author: Verma Neelam 
Fig.2.2: Zooplankton species in different station of Lower lake during year 2005-2006

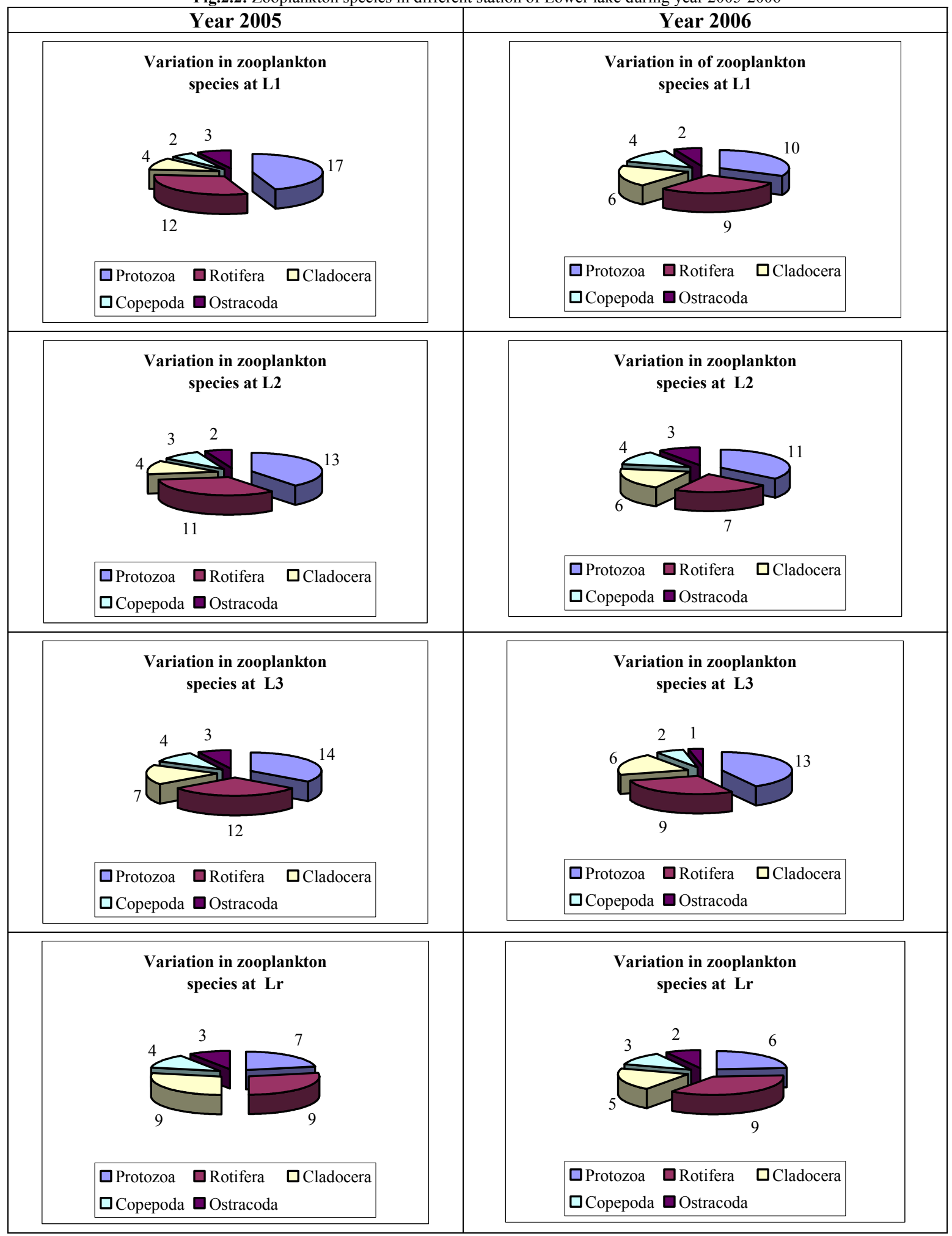

* Corresponding author: Verma Neelam 
Phytoplankton in Lower lake

Distribution of phytoplankton species at different sampling stations in Lower lake during study period shown in Fig.1.2

In Neelam Park (L1) station during 2005, total 51 species of phytoplankton population was recorded of which Chlorophyceae contributed 23 sp, Bacillariophyceae contributed 14 sp while Cyanophyceae $9 \mathrm{sp}$, Euglenophyceae $3 \mathrm{sp}$ and Dinophyceae 2 sp. During 2006 total 44 species of Phytoplankton population was recorded of which Chlorophyceae contributed 21 species, Bacillariophyceae contributed 12 species while Cyanophyceae was represented by 7 species, Euglenophyceae by 2 sp and Dinophyceae by 2 species.

In Khatlapura (L2) during 2005, total 58 sp were recorded of which $27 \mathrm{sp}$ Chlorophyceae, $17 \mathrm{sp}$ Bacillariophyceae, 4 sp Cyanophyceae, 10 Euglenophyceae and no species of Dinophyceae was recorded whereas during 2006, total $47 \mathrm{sp}$ were recorded of which $28 \mathrm{sp}$ belong to Chlorophyceae, 11 sp Bacillariophyceae, 4 sp Cyanophyceae, $2 \mathrm{sp}$ Euglenophyceae and 2 sp Dinophyceae was found.

In Bhoipura (L3) during 2005, total 37 species of phytoplankton population was recorded in which Chlorophyceae contributed 16 species, Bacillariophyceae contributed 11 species while Cyanophyceae was represented by 7 species, Euglenophyceae by $2 \mathrm{sp}$ and Dinophyceae by 1 species. During 2006, total 44 species of Phytoplankton population was recorded of which Chlorophyceae contributed 18 species, Bacillariophyceae contributed 17 sp while Cyanophyceae was represented by 6 species, Euglenophyceae by 2 sp and Dinophyceae by 1 species.

In Reference (Lr) sample during 2005, total 33 species of phytoplankton population was recorded of which Chlorophyceae contributed 9 species, Bacillariophyceae contributed 7 species while Cyanophyceae was represented by 17 species. During 2006, total 34 species of Phytoplankton population was recorded of which Chlorophyceae contributed 7 species, Bacillariophyceae contributed 12 species while Cyanophyceae was represented by 15 species and there is no species found of Euglenophyceae and Dinophyceae.

The Cyanophyceae groups are characteristic of eutrophic environments which have high concentrations of nutrients. Consequently, these represented the second most dominant group in the phytoplanktonic community. The Bacillariophyceae also had an increase number of individuals since they adapt better to more stable environments during aeration and ozonization. The Euglenophyta group was represented by few species which is very common in these environments. The mechanical aeration caused the dominance of the Chlorophyta with greater species diversity. Misra et. al. (2001) reported 94 phytoplankton species of above mention group in Upper lake and 88 species in Lower lake.

\section{Zooplankton in Upper lake}

Distribution of zooplankton species at different sampling stations in Upper lake during study period shown in Fig.2.1.

In Medical college (U1) during 2005, total 33 species were recorded of which 8 sp belong to Protozoa, $9 \mathrm{sp}$ belong to Rotifera, 5 to Cladocera, 7 to Copepoda and 4 to Ostracods. In the year 2006, total 30 species were recorded of which $6 \mathrm{sp}$ Protozoa, $11 \mathrm{sp}$ Rotifera, 6 sp Cladocera, 4 sp Copepoda and $3 \mathrm{sp}$ Ostracods.

In Khanugaon (U2) during 2005, total 36 species were recorded of which 6 sp belong to Protozoa, 10 sp belong to Rotifera, 9 to Cladocera, 7 to Copepoda and 4 to Ostracods whereas in the year 2006, total 39 species were recorded of which $11 \mathrm{sp}$ belong to Protozoa, 14 sp belong to Rotifera, 7 to Cladocera, 5 to Copepoda and 2 to Ostracods.

In reference (Ur) sample during 2005, total 23 species were recorded of which 2 sp belong to Protozoa, $11 \mathrm{sp}$ belong to Rotifera, 6 to Cladocera, 2 to Copepoda and 2 to Ostracods while in the year 2006, in reference sample total 45 species were recorded of which $4 \mathrm{sp}$ belong to Protozoa, $18 \mathrm{sp}$ belong to Rotifera, 11 to Cladocera, 4 to Copepoda and 8 to Ostracods.

\section{Zooplankton in Lower lake}

Distribution of zooplankton species at different sampling stations in Lower Lake during study period shown in Fig.2.2

In Neelam Park (L1) during 2005, total 38 species of zooplankton population was recorded of which Protozoa contributed $17 \mathrm{sp}$, Rotifera contributed 12 $\mathrm{sp}$ while Cladocera was represented by $4 \mathrm{sp}$, Copepoda by 2 sp and Ostracoda by 3 sp. During 2006, total 31 species of zooplankton population was recorded of which Protozoa contributed $10 \mathrm{sp}$, Rotifera contributed $9 \mathrm{sp}$ while Cladocera was represented by $6 \mathrm{sp}$, Copepoda by $4 \mathrm{sp}$ and Ostracoda by 2 species.

In Khatlapura (L2) during 2005, total 33 species of zooplankton population was recorded of which Protozoa contributed $13 \mathrm{sp}$, Rotifera 11 sp while Cladocera was represented by $4 \mathrm{sp}$, Copepoda by 3 sp and Ostracoda by 2 sp whereas during 2006, total 31 species of zooplankton population was recorded in which Protozoa $11 \mathrm{sp}$, Rotifera $7 \mathrm{sp}$ while Cladocera $6 \mathrm{sp}$, Copepoda $4 \mathrm{sp}$ and 3 species of Ostracoda was found. 
In Bhoipura (L3) during 2005, total 40 species of zooplankton population was recorded of which Protozoa contributed 14 sp, Rotifera contributed 12 sp while Cladocera was represented by $7 \mathrm{sp}$, Copepoda by $4 \mathrm{sp}$ and Ostracoda by $3 \mathrm{sp}$. During 2006 total 31 species of zooplankton population was recorded of which Protozoa contributed $13 \mathrm{sp}$, Rotifera contributed $9 \mathrm{sp}$ while Cladocera was represented by $6 \mathrm{sp}$, Copepoda by $2 \mathrm{sp}$ and Ostracoda by 1 sp.

In Reference (Lr) sample during 2005, total 32 species of zooplankton population was recorded of which Protozoa contributed $7 \mathrm{sp}$, Rotifera $9 \mathrm{sp}$ while Cladocera 9 sp, Copepoda $4 \mathrm{sp}$ and Ostracoda $3 \mathrm{sp.}$ During 2006 total 25 species was recorded of which Protozoa contributed 6 sp, Rotifera 9 sp while Cladocera 5 sp, Copepoda 3 sp and Ostracoda 2 sp.

In Upper and Lower lakes distribution of zooplankton were largely regulated by various factors. In most lakes zooplankton are the central trophic link between primary producers and fish. Zooplankton is ubiquitous in all lakes and quickly and easily sampled in the field (Pani et. al., 2000). Zooplankton species richness is reduced under chemical stresses (Barker \& Christensen 1991) and abundant large Daphnia are associated with clear lakes with healthy sport fish populations (Mazumdar, 1994). Zooplankton composition and abundance of these lakes were observed variable with respect to time and location. Pani et. al., (2000) recorded 29 zooplankton species in Upper lake and 38 species in Lower lake. Verma (2007) studied the distribution of micro flora and fauna in Upper and Lower lakes.

Conclusion: Biodiversity contributes both directly and indirectly to many constituents of human wellbeing, including security, basic material for a good life, health, good social relations, and freedom of choice and action. Over the last century, many people have benefited from the transformation of natural ecosystems and the exploitation of biodiversity, but the losses in biodiversity and changes in ecosystem services have adversely affected the well-being. The present study reveals that Upper and Lower lakes are rich in micro as well as macro flora and fauna. The distribution of aquatic macrophytes in Bhoj Wetland explains that both lakes are rich in planktonic biodiversity.

\section{REFERENCES}

APHA (1995). Standard methods for examination of water and wastewater, $16^{\text {th }}$ edition, American Public Health Association, Washington DC, USA.

Bajpai, A. (1994). Study of nutrient enrichment through catchment area with reference to Upper lake, Bhopal. Ph.D. Thesis, Barkatullah University, Bhopal.

Bajpai, A., Bajpai, A.K., Pani, S., Misra, S.M. (2001). Pollution and trophic status indicator species of Bhoj Wetland. Ecol. Env. \& Cons., 7, 3, 245-249.

Baker, J.P., Christensen, S.W. (1991). Effects of acidification on biological community in aquatic ecosystem. In D.F. Charles, ed. Acidic deposition and aquatic ecosystem: Regional case studies. Springer-Verlag, New York. 83-106.

Campbell, N.(1990). Introduction to Biological Evolution From Biology, 2nd Edition, Benjamin/Cummings Publishing.

Charles, D.F., Smol, J.P. (1994). Long term chemical changes in lakes: Quantitative inference using biotic remains in the sediment record. Advances in chemistry. 237, 1-57.

Dixit, S.S., Smol, J.P., Kingston, J.C., Charles, D.F. (1992). Diatoms: powerful indicators of environmental change. Environmental Science and Technology. 26, 23-33.

Harper, D. (1992). Eutrophication of freshwaters. Chapman and Hall, London. 321.

Hutchinson, G.E. (1957). A treatise on imnology. Vol. 1, Geography, Physics and Chemistry John Wiley \& Sons, New York, NY 1015.

Jana, B.B., Das, S.K. (1995). Phosphorus in aquatic systems: An overview advances in ecology and environmental sciences. Ashish Publishing House, New Delhi.

Mason, C.F. (1991). Biology of freshwater pollution. Longman Scientific and Technical, New York. 2nd Edi. 95-138.

Mazumdar, A. (1994). Pattern of algal biomass in dominant odd vs even link ecosystems. Ecology. 75 (4), 1141-1149.

Misra, S.M., Pani, S., Bajpai, A., Bajpai, A.K. (2001). Assessment of trophic status by using Nygaard index with special reference to Bhoj Wetland. Poll. Res. 20 (2), 147-153.

Pani, S., Bajpai, A.K., A., Dubey, A., Misra, S.M. (2000). Evaluation of water quality of Bhoj Wetland through matrics determination. In: Proceedings, National workshop on biodiversity

* Corresponding author: Verma Neelam 
\& conservation of aquatic resources with reference to threatened fish mahseer, Bhopal. pp 96-108.

Ramsar Convention (2007). Available online Ramsar Convention web (http://ramsar.org/profile index.htm). 18.

Ryder, R.A., Kerr, S.R., Loftus, K.H., Regier, H.A. (1974). The morphoedaphic index, a fish yield estimator: Review and evaluation. Journal of Fisheries Research Board of Canada 31:663-668.

Salas H.J., Martino Y.P. (1990). Metodologias simplificadas para Evaluaciaon de Eutroficacion en Lagos Calidos Tropicales 1981-1990.
Programa Regional Centro Panamericano de Ingenieria Sanitaria y Ciencias del Ambiente, organizacion Mundial de la Salud, organizacion Panamericano de la Salud, Lima, Peru. 51.

Stevens, M.R. (2003). Water quality and trend analysis of Colorado big Thompson system Reservoir \& related conveyances, 1969 through 2000. Water Resource Investigation Report, 034004 (http:// www.usgs.gov) 155.

Verma, N. (2007). Studies on aeration units in restoration of water quality with reference to upper and lower lake, Bhopal. Ph.D. Thesis. Barkatullah University, Bhopal, India.

* Corresponding author: Verma Neelam 